\title{
Work Attitude and Performance of Elementary School Teachers in the City Division of San Carlos
}

\author{
Kristine Jane C. Hermogeno ${ }^{1}$, \& Cristeta C. Dulos ${ }^{2}$ \\ ${ }^{1}$ Teacher I-Jose Macam Paningbatan Sr. Elementary School, Philippines, 2420 \\ ${ }^{2}$ Professor-Pangasinan State University - School of Advanced Studies, Philippines, 2428 \\ DOI - http://doi.org/10.37502/IJSMR.2022.5102
}

\begin{abstract}
This study aimed to determine the work attitude and performance of one hundred seventy-six (176) elementary school teachers in the City Division of San Carlos. It utilized the descriptive method of research with the survey questionnaire checklist as the main instrument in gathering the needed data. Frequency, percentage distribution, average weighted mean, ANOVA, Pearson and Chi-Square, T-test and Analysis of Variance were employed to analyze and interpret the data. The study found out that majority of the respondents are female, generally middle-aged, married with bachelors' degree. Most of them are generalist assigned in Grade 5 and are occupying Teacher III position with no designation and awards received. This study also found out that the IPCRF rating of the teachers for the school year 2018-2019 is Very Satisfactory. Results have shown that the extent of manifested work attitude along subjects taught, superior/school head, co-worker, learners, school environment, parents and recognition/award/promotion are generally Very Highly Manifested. While the extent of manifested work attitude along incentives/rewards is Highly Manifested. This study also revealed that there is no significant relationship between the extent of manifested work attitude and teachers' performance. Lastly, there is a significant difference between the teachers' performance across teachers' profile.
\end{abstract}

Keywords: Manifestation, Performance, Work attitude, IPCRF, Elementary school teachers

\section{Introduction}

Teaching has been known to be the foremost demanding job since teachers need a long time to work out the result of their actions on their students. It's like planting a tree; one should watch for an extended time for the tree to finally mature. Apart from the tedious classroom preparations and also the task dealing individually with diverse learners, teachers are expected to be engaged in numerous kinds of community activities and other out-of-school assignments. Hence, there are various roles which teachers face seem to be exhausting and stressful. Meador [1] described teaching as a difficult profession.

There are number of things that may influence a good teacher of a school: intelligence, skill, training and others. However, as important of those matters, there is a fair greater and more influential factor: attitude. 
As defined by Sarong [2], attitude is an inward feeling expressed by outward behavior. People always show on the surface what they feel on the within. A person's attitude colors every aspect of his/her life. It's like the mind's paintbrush. It can paint everything in bright, vibrant colors -creating a masterpiece or it can make everything dark and lifeless. There is not a single part of a person's current life that is not littered with his/her attitude.

How teachers behave at work often depends on how they feel about being there. Therefore, making sense of how teachers behave depends on understanding their work attitudes. Teachers may possess different work attitude toward teaching. Little doubt, work attitude depends upon factors, especially among teachers, the factors being within the school, the colleagues, the children, the value system and views of life. This is accordingly interweaved with positive or negative work attitude of teacher towards pupils, the profession, classroom activities and also the administration. A teacher who works professionally manifests proper work attitude towards work. He knows what his work is about, always maintain high standards of performance consistent with the strain by his superiors or demanded by his particular job. So, teachers' work attitudes are significant in understanding and improving educational process.

Teachers' work attitude towards their profession have an impact on their performance too. The attitude and experiences of teachers affect not only the performance of the learners but also their own teaching performances. Their work attitude towards their tasks would eventually shape their individual styles that in turn would either be a success or failure in their career. Additionally, in keeping with Senemoglu [3] attitude is an acquired internal state that affects individual's personal activity preferences towards a group of things, individuals, events and various situations. It is essential to boost the standard of teaching profession (Koksal [4]), a vital factor that affects teacher's success (Abu Sharbain \& Tan [5]) and efficiency (Guneyli \& Aslan [6]; Abu Sharbain \& Tan [5]). It's also found to be associated with gender (Akkaya [7]), teacher's competence (Abu Sharbain \& Tan [5]) and pupil control ideology of teacher candidates (Oguz \& Kalkan [8]).

Most of the time, the climate of the classroom which is set by the teacher is additionally determined by the teacher's work attitude. Attitude as a serious determinant of a person's behavior, influences the way a teacher relates with the students and thus affects pupil's academic achievement. Moreover, personality traits of the teachers are more powerful and influential than the course content or instructional strategies utilized in the classroom. A pleasant classroom strategy requires full interest and support from teachers and learners. If a teacher is not interested or careful about a particular subject or student, he/she will be unable to nurture a supportive learning environment. Even the skillful and most talented teacher is not effective when he or she does not possess an honest attitude in his or her workplace. On the opposite hand, teachers whose positive perspective of commitment and dedication lead them to high levels of effort often excel even once they don't seem to be the skillful and talented teachers. Schools have grown increasingly conscious of the importance of this matter and are investing longer and putting effort than ever to make the positive work attitude possible among their teachers. Since the teacher can mostly influence the young, he or she must set examples to them. Work attitude is closely associated with teachers' strategies for handling challenges in their day-to-day professional life and to their general well-being. This also shape pupils' learning environment and influence pupils' motivation and achievement. 
Considering all of these reasons, it may be said that teachers face different difficulties once they start teaching. Guneyli \& Aslan [6] stated that prospective teachers presupposed to be happy to teach even under difficult conditions.

Work performance on the other hand, could be a complex construct, taking into consideration the changing nature of labor and therefore the organizations themselves. It speaks of work performance in terms of quantity and quality expected from each employee.

Thorndike as cited by Labadia [9] started the method of defining work performance by articulating the final word criterion. He further explains that the ultimate basis is conceptual in nature and cannot be measured. Additionally, Kessler [10] conceptualized the factors in assessing work performance by choosing between subjective and objective methods of appraisal. The "soft" criteria like peer, self, or supervisory ratings refer to subjective methods. It is generally recognized that teachers who possess a positive work attitude are more productive and useful to the school.

One of the foremost factors that is related to teachers' work attitude and performance is job satisfaction. The sentiments people have toward their job refers to job satisfaction. If the number of studies conducted on job satisfaction is an indicator, job satisfaction is maybe the foremost important job attitude. Fuming and Jiliang [11] focus in their study of job satisfaction in Chinese schools that means, "Overall job satisfaction means the workers' attitude toward all aspects of labor and therefore the work environment, that is, the workers' overall reaction to their add its entirety". Okoye [12] believed that job satisfaction is how contented a personal is along with his or her job. An individual may be satisfied with one aspect of his/her job arid be dissatisfied with other aspects. It can positively build up an employee's work attitude because he is likely to be more motivated and dedicated to achieving organizational goals or realizing the goals of elementary school education. In an exceedingly qualitative study focused on examining factor that impact teacher retention in North Carolina, Mccoy, and Wilson-Jones \& Jones [13] found that salary, working conditions, and lack of support are the most commonly indicated reasons for leaving the profession. Supported interviews from both beginning and seasoned teachers, a major factor about their decisions to leave teaching is lack of support from mentors, colleagues, but generally from school administrators.

Establishing a relationship between Self-Determination Theory and work motivation, Gagné and Deci [14] continue, "SDT focuses not only on job characteristics like choice and constructive feedback as one way to influence autonomous motivation, but it also suggests that the interpersonal type of supervisors and managers is essential". In education, superintendent, supervisors, principals and department chairs are inclined to possess an immediate influence on the daily work experience of teachers, but every level of school supervision influences the factors of professional development, school climate and support.

In addition to this, Okonkwo \& Obineli [15] emphasized that several teachers in public schools lack motivation and job satisfaction due to poor salary and poor work environment. When a teacher enjoys the work environment and therefore the numerous tasks that distinguish his/her job situation, it is expected that such a teacher would have a powerful desire to come to work and perform assigned duties actively.

Ewen [16] explained that teachers' satisfaction is directly connected with the standard and quantity of coaching and career opportunities provided further training of teachers is another inevitable factor in the teaching and learning process. In order to enhance the performance of 
workers and greatly increase productivity, the government and all employers of labor normally embark on staff development programs. Klecker and Loadman, [17] carried out a research where their findings indicated that teachers' job satisfaction measured teachers' satisfaction with salary, opportunities for advancement, degree of challenge of the work, autonomy, working conditions, interaction with colleagues and students. It therefore concludes that manpower development programs increase job satisfaction and non-availability of such schemes results into great dissatisfaction with the job.

In the present day, one among the most concern of parents, communities and students is the quality of education, where teacher is a vital determining factor in the method of education. The parameters of teaching and learning is defined by the positive attitude of teachers towards their profession. Thus, the emotions, interests of teachers affect their own performance. Teachers with positive attitude competently contribute to the method of child's education. Personality of teacher is a role model for students. Effective teachers share their feelings honestly with their students. During this way, a relationship of trust is developed between teachers and taught (Brown and Richard [18]). It directly and positively impacts students' learning when teachers own the profession of teaching. Thus, they care, show kindness, accept diversity and share responsibility.

Based on these concepts, this paper aims to determine the work attitude and performance of elementary school teachers in the City Division of San Carlos. The results of the present study may help teachers in San Carlos City concerning teachers' work attitude and performance in elementary classrooms.

\section{Materials and Methods}

\subsection{Research Design}

Descriptive method of research design was utilized in this study. Responses to the 20192020 survey questionnaires were analyzed. The researcher collected data on the extent of manifested work attitude along subjects taught, superior/school head, co-worker, learners, school environment, parents, recognition/award/promotion and incentives/rewards.

This study is based on survey research in which data from gathered and analyzed statistically. Demographic information as well as responses to predetermined survey questions were collected and reviewed. A comparison of results was made with prediction.

\subsection{Respondents of the Study}

The respondents of the study were the 176 public elementary school teachers of the City Division of San Carlos during the school year 2019-2020.

The researcher selected 4 public schools in San Carlos City. The City Division of San Carlos has 4 Districts for elementary level. The researcher selected 1 large school for each District which has the large number of respondents. The respondents were determined using total enumeration who rendered one year and above in teaching in the public schools.

\subsection{Research Instrument}


The researcher used of a survey questionnaire checklist as the main instrument to identify work attitude and performance of elementary school teachers in the City Division of San Carlos. The questionnaire was of two parts. Part I of the questionnaire elicited information on the teacher characteristic which is divided into two: Personal Attributes and Professional Attributes. Personal Attributes were age, sex, civil status and highest educational attainment and under Professional Attributes were grade level handled, area/s of concentration, designation and recognitions or awards or distinctions received.

Part II elicited information on the extent of manifested work attitude along with the different variables. Responses of the respondents were measured using the four-point Likerttype scale, indicating the extent to which the teacher agreed $(1=1.00-1.74$ - lowly manifested, $2=1.75-2.49$ - moderately manifested, $3=2.50-3.24$ - highly manifested, $4=3.25-4.00$ - very highly manifested.)

To establish the validity of the questionnaire, the researcher requested the pool of experts on educational management to rate the items of the questionnaire. The evaluator's comments, suggestions and recommendations were considered in the final revision of the instrument. The evaluators gave it an average rating of High Valid. Thus, the questionnaire was valid.

\subsection{Data-Gathering Procedure}

The researcher requested the permission from the Division Superintendent of San Carlos City Division, the School Heads and the teachers of the different public elementary schools the conduct to float the questionnaires. This was done to gain full support from the administrative staff.

To gather the needed data, the survey questionnaire checklist was personally administered, distributed and facilitated by the researcher. The respondents were brief on the significance of the survey so honest responses were elicited from them.

The researcher also gathered the summary of the IPCRF Rating of teachers from the selected large schools of the study which was needed to determine the performance rating of the teachers.

\subsection{Statistical Treatment of Data}

Responses on the questionnaire by elementary school teachers were statistically analyzed with the data requirements of the study. The researcher used appropriate statistical tools, which were necessary for the objective interpretation and evaluation of the data gathered.

Frequency counts and percentages were used to determine the profile of the elementary teachers of the City Division of San Carlos during the SY 2019-2020.

Descriptive statistics such as mean, standard deviation, skewness and kurtosis was used to determine the performance of the elementary teachers.

The extent of the manifestation of the work attitude was analyzed using the average weighted mean. It was discussed using the mean scale range below: 
Table 1. Level of work attitude scale with description

\begin{tabular}{ccc}
\hline Choice & Mean Scale Range & Descriptive Equivalent \\
\hline 4 & $3.25-4.0$ & Very Highly Manifested \\
3 & $2.50-3.24$ & Highly Manifested \\
2 & $1.75-2.49$ & Moderately Manifested \\
1 & $1.00-1.74$ & Lowly Manifested \\
\hline
\end{tabular}

The Pearson $r$ and Chi-Square Statistical Tests were used to test the significant relationship between the extent of manifested work attitude and teachers' performance.

T-test and Analysis of Variance were utilized to determine to test the significant difference between the teachers' performance across teachers' profile.

\section{Results and Discussion}

Table 2 shows the personal attributes of elementary school teachers in terms of their age, sex, civil status and highest educational attainment. While table 3 presents the professional attributes, which include their grade level handled, areas of concentration, designation and recognition/award/distinction received.

Table 2. Personal Attributes of Elementary School Teachers in the City Division of San Carlos

\begin{tabular}{cccc}
\hline Personal Attributes & Category & F & \% \\
\hline \multirow{2}{*}{ Age } & Below 30 & 21 & 11.9 \\
& $30-39$ & 53 & 30.1 \\
& $40-49$ & 71 & 40.3 \\
Total & $50-59$ & 24 & 13.6 \\
Sex & 60 and above & 7 & 4.0 \\
& & 176 & 100.0 \\
Total & Male & 14 & 8.0 \\
& Female & 162 & 92.0 \\
Civil Status & Single & 176 & 100.0 \\
& Married & 27 & 15.3 \\
Total & Widowed & 146 & 83.0 \\
Highest Educational & Divorce & 3 & 1.7 \\
Attainment & & 0 & 0 \\
& Bachelor's Degree & 176 & 100.0 \\
Total & Master's Degree & 113 & 64.2 \\
& Doctoral's Degree & 60 & 34.1 \\
& & 3 & 1.7 \\
& & 176 & 100.0 \\
\hline
\end{tabular}

Age. It could be gleaned on the table that majority of the elementary school teachers are 4049 years old as evidenced by seventy-one (71) or $40.3 \%$. There are fifty-three (53) or $30.1 \%$ elementary school teachers who are 30-39 years old. There are also $13.6 \%$ or twenty-four (24) elementary school teachers whose age are 50-59. Below 30 years old, there are twenty-one (21) 
or $11.9 \%$ of them. However, only seven (7) of them are 60 and above as supported by the percentage of 4.0.

The data imply that there are more teachers whose age range from forty to forty-nine than the young and senior citizens' teachers.

Sex. The table shows that most of the respondents are female as evidence by the frequency of one hundred sixty-two (162) or $92.0 \%$ while only fourteen (14) of them are male as indicated by the $8.0 \%$. The result supports the common notion that teaching is still a female-dominated profession.

Civil Status. The table shows that majority of the respondents are married as supported by the frequency of one hundred forty-six (146) or 83.0\%. There are twenty-seven (27) or $15.3 \%$ of them who are still single. However, only three (3) of them are widowed as indicated by the percentage of $1.7 \%$.

The data imply that teachers are family-oriented who really value the essence of having families. This signifies that Filipinos adhere to the prime importance of rearing family bonded by the sacrament of marriage.

Highest Educational Attainment. It could be seen on the table that one hundred thirteen (113) or $64.2 \%$ of the teachers are bachelor's degree holders. There are sixty (60) of them who earned master's degree with a percentage of $34.1 \%$. While there are only three (3) or $1.7 \%$ of them who earned doctorate degree.

The data support the study of Galiza, et.al. [19] Where they revealed that of the 68 respondents $(68 \%)$ who have units in master's degree, only eight acquired units in chemistry and only one (1\%) graduated with a Master's degree directly related to chemistry. Twenty-one (21) respondents $(21 \%)$ earned bachelors' degree. Six respondents $(6 \%)$ completed their Master's degree while only 4 respondents (4\%) have doctoral units (Educational Management and Mathematics). One respondent (1\%) has completed a doctoral degree major in Educational Management.

Majority of the respondents were enrolled in graduate school and have earned units for their Master's degree. Based on the interview, most of the teachers who were over 40 years old and above had no interest in pursuing their career to the next level. They did not see any more the benefit that they could get from it. One of them even mentioned that she already achieved the peak of her career as a teacher. During the interview of teachers, head teachers, and principal, two (2) of the interviewees strongly recommend that teachers must pursue further studies to be able to improve one's science content knowledge. To be able to be promoted to a higher position, a master's degree or at least 18 units in the master's program is one of the qualifications.

Many school districts and states have long encouraged teachers to pursue graduate education. According to Hill [20], teachers are commonly permitted to use graduate credits for recertification. Generally, teachers with graduate degrees earn a higher salary or receive an annual stipend (Miller \& Roza [21]).

In early childhood and primary schools (pre-kindergarten through grade 6), teachers with a master's degree relative to only a bachelor's degree have not had a greater influence on student reading achievement (Collier [22]; Croninger, Rice, Rathbun, \& Nishio, [23]; Harris \& Sass [24]; Henry, Bastian, Fortner, Kershaw, Purtell, Thompson, \& Zulli [25]; Jepsen [26]; 
Rivkin, Hanushek, \& Kain [27]). However, mixed results were yielded in studies examining the effect of teacher educational attainment on student Math achievement in K-6 schools. Another study revealed that Math achievement scores of students whose teachers had a master's degree were significantly higher than those of students whose teachers did not have a master's degree (Collier [22]).

Table 3. Professional Attributes of Elementary School Teachers in the City Division of San Carlos

\begin{tabular}{|c|c|c|c|}
\hline Professional Attributes & Category & $\mathbf{F}$ & $\%$ \\
\hline \multirow[t]{8}{*}{ Grade Level Handled } & Kinder & 17 & 9.7 \\
\hline & Grade 1 & 24 & 13.6 \\
\hline & Grade 2 & 23 & 13.1 \\
\hline & Grade 3 & 20 & 11.4 \\
\hline & Grade 4 & 24 & 13.6 \\
\hline & Grade 5 & 32 & 18.2 \\
\hline & Grade 6 & 29 & 16.5 \\
\hline & Two/more grade levels & 7 & 4.0 \\
\hline Total & & 176 & 100.0 \\
\hline \multirow[t]{12}{*}{ Area/s of Concentration } & $\begin{array}{l}\text { Early Childhood } \\
\text { Education }\end{array}$ & 17 & 9.7 \\
\hline & General Education & 71 & 40.3 \\
\hline & English & 10 & 5.7 \\
\hline & Social Studies & 9 & 5.1 \\
\hline & MAPEH & 5 & 2.8 \\
\hline & Mathematics & 13 & 7.4 \\
\hline & Filipino & 9 & 5.1 \\
\hline & Science & 6 & 3.4 \\
\hline & TLE & 8 & 4.5 \\
\hline & ESP & 2 & 1.1 \\
\hline & Special Education & 6 & 3.4 \\
\hline & $\begin{array}{l}\text { More than one area of } \\
\text { concentration }\end{array}$ & 20 & 11.4 \\
\hline Total & & 176 & 100.0 \\
\hline \multirow[t]{5}{*}{ Position } & Teacher I & 31 & 17.6 \\
\hline & Teacher II & 23 & 13.1 \\
\hline & Teacher III & 107 & 60.8 \\
\hline & Master Teacher I & 10 & 5.7 \\
\hline & Master Teacher II & 5 & 2.8 \\
\hline Total & & 176 & 100.0 \\
\hline \multirow[t]{3}{*}{ Designation } & $0-1$ & 169 & 96.0 \\
\hline & $2-3$ & 6 & 3.4 \\
\hline & 4 and above & 1 & 0.6 \\
\hline Total & & 176 & 100.0 \\
\hline Recognitions/Awards/ & No award & 153 & 86.9 \\
\hline \multirow[t]{2}{*}{ Distinctions } & One award & 16 & 9.1 \\
\hline & Two or more awards & 7 & 4.0 \\
\hline Total & & 176 & 100.0 \\
\hline
\end{tabular}


Grade Level Handled. The table shows that majority of the respondents are handling Grade 5 as supported by the frequency of thirty-two (32) or $18.2 \%$.

There are twenty-nine (29) of them who are handling Grade 6 as evidenced by the percentage of $16.5 \%$. In addition, the frequency of respondents who are handling Grade 1 and Grade 4 are twenty-four (24) as indicated by $13.6 \%$. Twenty-three (23) or $13.1 \%$ of them are handling Grade 2, twenty (20) or $11.4 \%$ in Grade 3, and only seven (7) or $4.0 \%$ of them are handling two or more Grade levels.

The data imply that there are more teachers who are handling intermediate grade levels than the primary grade levels because there are more subjects to be taught in higher grade levels which need more teachers to teach

Area/s of Concentration. It could be seen in the table that majority of the respondents' concentration is General Education as evidenced by the frequency of seventy-one (71) or $40.6 \%$ while only two (2) or $1.1 \%$ of them have the concentration along Edukasyon sa Pagpapakatao (ESP). Twenty (20) of the respondents have more than one area of concentration as supported by the percentage of $11.4 \%$.

The result supports that generalist teachers are most commonly found teaching in Kinder to 6. They are able to teach all basic subjects, often to more than one grade level. They are also equipped to teach character education, physical education, including music, health and wellness classes

Position and Designation. It could be gleaned in the table that majority of the respondents are Teacher III as supported by the frequency of one hundred seven (107) or $60.8 \%$. While there are only five (5) or $2.8 \%$ of them who are Master Teacher II. The table also shows that majority of them have zero to one (0-1) designation with a frequency of one hundred sixty-nine (169) or $96 \%$. Only one (1) or $0.6 \%$ of them has more than four designations.

The data signify that teachers who are competent deserve to be promoted in higher positions they are qualified to. This indicates that more than half of the respondents were promoted to Teacher III position while there are only few who were promoted to Master Teacher I and II. Promotion can therefore be considered as the passage to a better rank.

Recognitions/Awards/Distinctions. The table shows that majority of the respondents has no award yet as indicated by the frequency of one hundred fifty-three (153) or $86.9 \%$. While only seven (7) or $4.0 \%$ has two or more awards. There are sixteen (16) or $9.0 \%$ of them who received one award.

The result signifies that majority of the respondents haven't received any recognition/award/distinction because they are bachelor's degree holders and are occupying Teacher III position.

The data also support the Gallup research authored by Hodges [28] that only $29 \%$ of teachers strongly agree with the statement, "In the last seven days, I have received recognition or praise for doing good work." Gallup Research shows that consistent recognition for doing good work features a direct impact on the key performance measures that use to evaluate schools. 
Table 4. Summary of the IPCRF Rating of Elementary School Teachers in the City Division of San Carlos SY 2018-2019

\begin{tabular}{cccc}
\hline & Rating & Frequency & Percent \\
\hline Valid & Very Satisfactory & 132 & 75.0 \\
& Outstanding & 44 & 25.0 \\
& Total & 176 & 100.0 \\
Mean & & 4.2500 & \\
\hline
\end{tabular}

IPCRF Rating. The table shows that majority of the respondents earned a Very Satisfactory Rating during the School Year 2018-2019 as evidenced by the frequency of one hundred thirty-two (132) or $75.0 \%$. While there are only forty-four (44) or $25.0 \%$ of them are Outstanding. The AWM rating is 4.2500 which is equivalent to Very Satisfactory.

The description for the Outstanding Rating is where performance represents a level of achievement which is extraordinary and commitment in terms of quality and time, technical skills and knowledge, ingenuity, creativity and initiative. Employees at this performance level should have demonstrated excellent job mastery in all areas of responsibility. Employee contributions to the organizations and achievement are excellence. While the description for Very Satisfactory Rating is where performance exceeded expectations. All goals, objectives and target were attained above the set standards.

The result also confirms the study of Nemenzo [29] entitled Problems Encountered by Teachers in Teaching-Learning Process that $83.94 \%$ got a "very satisfactory" rating in their performance. This implies that teachers work hard to pass the evaluation for teachers. Besides, IPCRF is an effective tool to evaluate the performance of the teachers. This signifies that teachers are performing good based upon their Means of Verification (MOV's). Furthermore, to evidently show task in accordance with the rating, teachers exert more effort and time to really comply with this. In connection to this, quality education through effective teaching and learning is the ultimate goal of every school. This IPCRF serves as a self-reflection of the teachers to better improve their practices or strategies in teaching.

Subjects Taught. The data on table 5 shows that the item "As teachers, we are eager to attend seminars or trainings in relation to the subject, we are handling which would help us improve our teaching skills", obtained the highest mean of 3.63 verbally interpreted as "Very Highly Manifested'. The item "As teachers, we find it easy to deliver the content of the subject we are handling", obtained the lowest mean of 3.33 verbally interpreted as "Very Highly Manifested". The AWM rating is 3.50 which is verbally interpreted as "Very Highly Manifested".

The data signify that teachers are motivated to learn and gain more insights on how to teach such subjects. This also strengthen their skills in the process as they improve their practices throughout their career because good teachers become great teachers by going beyond the box and explore the other things that interest them.

Furthermore, according to Desimone [30] professional development has been defined as activities that may assist teachers by providing them information about instructional methods. This information is shared formally in seminars and conferences or informally between teachers. 
Arnau [31] said that no longer are teachers confined to classrooms without accountability. Teachers are expected to be learning and leading professionals in today's reform-and policydriven educational culture. (Hirsh [32]).

Table 5. Extent of Manifested Work Attitude along Subjects Taught

\begin{tabular}{|c|c|c|c|c|c|c|}
\hline & $\begin{array}{l}\text { Subjects taught. As teachers, } \\
\text { we (are)... }\end{array}$ & 2 & 3 & 4 & Mean & DE \\
\hline & $\begin{array}{l}\text { Eager to attend seminars or } \\
\text { trainings in relation to the } \\
\text { subject we are handling which } \\
\text { would help us improve our } \\
\text { teaching skills. }\end{array}$ & 1 & 64 & 111 & 3.63 & VHM \\
\hline 2. & $\begin{array}{l}\text { Happy and excited teaching the } \\
\text { subject. }\end{array}$ & 3 & 65 & 108 & 3.60 & VHM \\
\hline 3. & $\begin{array}{l}\text { Motivated to try out new ideas } \\
\text { in our classroom as part of } \\
\text { teaching the subject. }\end{array}$ & 11 & 61 & 104 & 3.53 & VHM \\
\hline & $\begin{array}{l}\text { Well-prepared whenever we } \\
\text { teach the subjects we are } \\
\text { handling. }\end{array}$ & 10 & 82 & 84 & 3.42 & VHM \\
\hline \multirow[t]{2}{*}{5.} & $\begin{array}{l}\text { Find it easy to deliver the } \\
\text { content of the subject we are } \\
\text { handling. }\end{array}$ & 13 & 92 & 71 & 3.33 & VHM \\
\hline & Total & 38 & 364 & 478 & 3.50 & VHM \\
\hline
\end{tabular}

Superior/School Head. It could be gleaned from the table that the item "As teachers, we feel appreciated when it comes to our work and efforts" garnered the highest mean as evidenced by 3.38 which is verbally interpreted as "Very Highly Manifested". While the item "As teachers, we feel comfortable raising issues and concerns to our principal which are important to the school" got the lowest mean of 3.28 verbally interpreted as "Very Highly Manifested". The AWM rating is 3.34 verbally interpreted as "Very Highly Manifested."

The result signifies that having a supportive school head can make a difference for a teacher. It is the responsibility of the school head to provide ongoing, collaborative teacher support. Studies show that appreciating teachers for great work actually helps make them better teachers. According to Gallup research authored by Hodges [28], in an era of school board politics and budget woes, recognizing teachers is an easy win for any community. It does not require a large investment of money or time. The research also shows that recognition needs two things to be effective. It must be individualized and frequent. Administrators should establish a "recognition-rich environment" with praise coming from all directions. 
Table 6. Extent of Manifested Work Attitude along Superior/School Head

\begin{tabular}{|c|c|c|c|c|c|c|c|}
\hline & $\begin{array}{l}\text { Superior/ School Head. } \\
\text { As teachers, we.... }\end{array}$ & 1 & 2 & 3 & 4 & Mean & DE \\
\hline & $\begin{array}{l}\text { Feel appreciated when it } \\
\text { comes to our work and } \\
\text { efforts. }\end{array}$ & 1 & 11 & 84 & 80 & 3.38 & VHM \\
\hline & $\begin{array}{l}\text { Feel supported and } \\
\text { encouraged by principal. }\end{array}$ & 1 & 16 & 80 & 79 & 3.35 & VHM \\
\hline 3. & $\begin{array}{l}\text { Need to talk to our principal } \\
\text { and we can do so with } \\
\text { relative ease. }\end{array}$ & 0 & 15 & 85 & 76 & 3.35 & VHM \\
\hline & $\begin{array}{l}\text { Feel the fairness and } \\
\text { openness of our principal. }\end{array}$ & 1 & 16 & 81 & 78 & 3.34 & VHM \\
\hline \multirow[t]{2}{*}{5.} & $\begin{array}{l}\text { Feel comfortable raising } \\
\text { issues and concerns to our } \\
\text { principal which are } \\
\text { important to the school. }\end{array}$ & 1 & 20 & 84 & 71 & 3.28 & VHM \\
\hline & Total & 4 & 78 & 414 & 384 & 3.34 & VHM \\
\hline
\end{tabular}

On the other hand, the item number five got the lowest mean. This is because the school head is the primary decision-maker in the school whenever there are problems to be faced. But this doesn't mean that teachers shouldn't be included in the decision-making process. Teachers should be given the opportunity to express their feelings or provide advice for the principal, especially when the issue will directly affect the teachers or the learners.

Co-Workers. According to Table 7, the item "As teachers, we can easily build friendship with our fellow teachers" obtained the highest mean 3.48 verbally interpreted as "Very Highly Manifested". While the item "As teachers, we regularly collaborate with our fellow teachers on methods and curriculum in the school where we work" obtained the lowest mean of 3.21 verbally interpreted as "Highly Manifested". The AWM rating is 3.32 which is verbally interpreted as "Very Highly Manifested. 
Table 7. Extent of Manifested Work Attitude along Co-Worker

\begin{tabular}{|c|c|c|c|c|c|}
\hline $\begin{array}{c}\text { C. Co- Workers. As teachers, } \\
\text { we.... }\end{array}$ & 2 & 3 & 4 & Mean & DE \\
\hline $\begin{array}{l}\text { 1. Can easily build friendship } \\
\text { with our fellow teachers. }\end{array}$ & 2 & 88 & 86 & 3.48 & VHM \\
\hline $\begin{array}{l}\text { 2. Easily get along with our fellow } \\
\text { teachers. }\end{array}$ & 5 & 98 & 73 & 3.39 & VHM \\
\hline $\begin{array}{l}\text { 3. feel comfortable whenever we } \\
\text { ask for help or assistance from } \\
\text { them. }\end{array}$ & 8 & 107 & 61 & 3.30 & VHM \\
\hline $\begin{array}{l}\text { 4. Feel professionally supported } \\
\text { by our fellow teachers in the school } \\
\text { where I work. }\end{array}$ & 7 & 123 & 46 & 3.22 & HM \\
\hline $\begin{array}{l}\text { 5. Regularly collaborate with our } \\
\text { fellow teachers on methods and } \\
\text { curriculum in the school where we } \\
\text { work. }\end{array}$ & 21 & 97 & 58 & 3.21 & HM \\
\hline Total & 43 & 513 & 324 & 3.32 & VHM \\
\hline
\end{tabular}

The data imply that being a good colleague will do the foremost good for teaching career. This is because teaching is about building relationships. The respondents can easily build friendship among their co-workers whose personalities and work ethics are similar with them and those what they respect. According to Participant Media [33], strengthening teacherfriendships is a means of forming happy and successful teachers who are more likely to collaborate with other, innovative in their teaching methods, and stay at any given school longer.

Learners. It could be gleaned from table 8 that there are two items that obtained the highest mean as evidenced by 3.57 verbally interpreted as "Very Highly Manifested." These items are "As teachers, we are always available to give learners the assistance they need" and "As teachers, we consistently enforce rules for learners' behavior even for learners who are not in their classrooms." While the item "As teachers, we can easily manage the misbehavior of our learners in the school where we work (such as noise, horseplay, or fighting in the halls, canteen or learners' lounge) which interferes with my teaching" obtained the lowest mean of 3.33 verbally interpreted as "Very Highly Manifested". The AWM rating is 3.48 which is "Very Highly Manifested."

The result supports the study of Hattie [34] where he noted that a harmonious classroom can help with the development of creativity and reduce anxiety levels amongst students. Teachers act as a powerful and effective means of support and encouragement when this may not always be available within the home environment.

Table 8. Extent of Manifested Work Attitude along Learners 


\begin{tabular}{lllllll}
\hline $\begin{array}{l}\text { D. Learners. As teachers, we } \\
\text { (are)... }\end{array}$ & $\mathbf{2}$ & $\mathbf{3}$ & $\mathbf{4}$ & Mean & DE \\
\hline $\begin{array}{l}\text { 1. Always available to give } \\
\text { learners the assistance they need. }\end{array}$ & 1 & 74 & 101 & 3.57 & VHM \\
$\begin{array}{l}\text { 2. Consistently enforce rules for } \\
\text { learners' behavior even for learners } \\
\text { who are not in their classrooms. }\end{array}$ & 9 & 99 & 68 & 3.57 & VHM \\
$\begin{array}{l}\text { 3. Provide learners with relevant } \\
\text { activities that support their learning }\end{array}$ & 1 & 92 & 83 & 3.47 & VHM \\
needs. \\
$\begin{array}{l}\text { 4. Feel the respect of my learners } \\
\text { towards us. }\end{array}$ \\
$\begin{array}{l}\text { 5. } \quad 4 \\
\text { misbehavior of our learners in the }\end{array}$ \\
$\begin{array}{l}\text { school where we work (such as } \\
\text { noise, horseplay, or fighting in the } \\
\text { halls, canteen or learners' lounge) } \\
\text { which interferes with our teaching. }\end{array}$
\end{tabular}

It is not unusual to find classrooms where rules and procedures are not explicit. This may happen if the teacher both believes that the students are conversant in classroom rules and that students do not need to be reminded about those rules (Piwowar. et.al. [35]). In addition to this, inconsistencies in rules' setting between teachers can also trigger disruptive behaviors. Also, when there aren't any rules or when rules are not specific, some students may test the limit of classroom order and may disturb the class, thus meddling with classroom activities. (Tauber [36]).

Table 9. Extent of Manifested Work Attitude along School Environment

\begin{tabular}{llllll}
\hline $\begin{array}{l}\text { E. School Environment. } \\
\text { As teachers, we (are)... }\end{array}$ & $\mathbf{2}$ & $\mathbf{3}$ & $\mathbf{4}$ & Mean & DE \\
\hline $\begin{array}{l}\text { 1. Generally satisfied being a } \\
\text { teacher in our school. }\end{array}$ & 4 & 69 & 103 & 3.56 & VHM \\
$\begin{array}{l}\text { 2. Have a school that is a } \\
\text { hazard-free and friendly school. }\end{array}$ & 1 & 95 & 80 & 3.45 & VHM \\
$\begin{array}{l}\text { 3. Provided with a safe, } \\
\text { conducive and orderly } \\
\text { environment for teaching and } \\
\text { learning. }\end{array}$ & & & & & \\
$\begin{array}{l}\text { 4. Feel the harmonious } \\
\text { relationship of our school with } \\
\text { the community. }\end{array}$ & 31 & 85 & 60 & 3.16 & VHM \\
$\begin{array}{l}\text { 5. Feel adequately supported } \\
\text { with our school's facilities } \\
\text { (workspace, furnishings..). }\end{array}$ & 38 & 96 & 42 & 3.03 & HM \\
$\quad$ Total & & & & & \\
\hline
\end{tabular}


School Environment. According to table 9, the item "As teachers, we are generally satisfied being a teacher in our school" obtained the highest mean of 3.56 verbally interpreted as "Very Highly Manifested". While the item "As teachers, we feel adequately supported with our school's facilities (workspace, furnishings...)" obtained the lowest mean of 3.03 verbally interpreted as "Highly Manifested." The AWM rating is 3.33 verbally interpreted as "Very Highly Manifested. According to the study of Kadtong, et.al. [37], majority of the teachers are somewhat satisfied on the following aspects of job satisfaction: school policies supervision, interpersonal relations, opportunities for growth and promotion, work itself, working conditions, achievement, recognition, and responsibility. This implies that teachers who are satisfied with their job are also productive. Satisfied employees tend to display behaviors that support organizational goals and objectives, be committed to the organization and excel at work. (Aamodt [38]: Lumley, et al. [39]).

On the other hand, school facilities also influence teachers especially in the teaching and learning process. According to Khan and Iqbal [40], adequate and quality school facilities are basic ingredients for quality education and to achieve the intended goal of the school program. It is difficult to serve large numbers of children with different learning abilities without adequate school facilities and resources.

The result also supports the study that good teachers need a workplace that uphold their efforts in different ways to retain their effective teaching and doing their best work with students. Teacher effectiveness is also about the conditions under which they work. Jackson [41] claimed that teachers as a contextual function of schools' working conditions are more or less effective that create human capital into productivity and effective instructional practice of teachers. Teachers' working conditions play a vital role in a school's ability to deliver high quality education. Schools that are able to provide their teachers a safe, pleasant, and supportive working environment can better attract and retain good teachers and even encourage them to do their best.

Parents. Table 10 shows that the item "As teachers, we welcome our parents/guardians wholeheartedly" obtained the highest mean of 3.69 verbally interpreted as "Very Highly Manifested." While the item "As teachers, we feel supported by the parents/guardians which contributes to our success in teaching the pupils" obtained the lowest mean of 3.27 verbally interpreted as "Very Highly Manifested." The AWM rating is 3.45 which is verbally interpreted as "Very Highly Manifested."

The data support the research of Khong [42], Lecturer in the Policy and Leadership Studies Academic group, NIE, that when schools reach and work with parents, their children feel supported, academically and holistically. Parents are vital important in every school. In addition to this, according to American Federation of Teachers, research shows that parental involvement can free teachers to focus more on task of teaching children. 
Table 9. Extent of Manifested Work Attitude along School Environment

\begin{tabular}{llllll}
\hline $\begin{array}{l}\text { F. School Environment. As } \\
\text { teachers, we (are)... }\end{array}$ & $\mathbf{2}$ & $\mathbf{3}$ & $\mathbf{4}$ & Mean & DE \\
\hline $\begin{array}{l}\text { 1. Generally satisfied being a teacher } \\
\text { in our school. }\end{array}$ & 4 & 69 & 103 & 3.56 & VHM \\
$\begin{array}{l}\text { 2. Have a school that is a hazard-free } \\
\text { and friendly school. }\end{array}$ & 1 & 95 & 80 & 3.45 & VHM \\
$\begin{array}{l}\text { 3. Provided with a safe, conducive } \\
\text { and orderly environment for teaching }\end{array}$ & 1 & 99 & 76 & 3.43 & VHM \\
$\begin{array}{l}\text { and learning. } \\
\begin{array}{l}\text { f Feel the harmonious relationship } \\
\text { of our school with the community. }\end{array}\end{array}$ & 31 & 85 & 60 & 3.16 & HM \\
$\begin{array}{l}\text { 5. Feel adequately supported with our } \\
\text { school's facilities (workspace, } \\
\text { furnishings...). }\end{array}$ & 38 & 96 & 42 & 3.03 & HM \\
$\quad$ Total & 75 & 444 & 361 & $\mathbf{3 . 3 3}$ & VHM \\
\hline
\end{tabular}

The result supports the study of Zeb, et.al. [44], that rewarding or recognizing certain desirable behaviors of an employee can lead to job satisfaction and the logical consequence of it is better performance. Their study also found out that employee's motivation in organizations can achieve their goals and aims through motivated employees and effective reward and recognition system.

In addition to this, according to the study conducted by Nyamubi [45], when teachers were provided with an opportunity for academic and professional development as well as timely promotion, they displayed happiness with the profession. This developed their advancement in the realm of skills, capacity, and experience. Sharma and Bajpai [46] also observe that employee's satisfaction with promotional opportunities depends on several factors, including the likelihood that employees perceive fairness within the encouragement process in terms of the timing of promotion after meeting the specified standards.

This result also lends credence to the view of Ewen [16] that promotion helps to boost workers' morale and motivates them to work thereby increasing productivity and efficiency and also increasing job satisfaction.

Incentives/Rewards. It could be gleaned from table 12 that there are two items which obtained the highest mean of 3.07 verbally interpreted as "Highly Manifested." These items are "As teachers, we always receive our salary on time with no delay" and "As teachers, we are encouraged to work more because the salary matches our efforts." While the item "As teachers, we feel ensured and stable in our teaching salary." obtained the lowest mean of 2.90 verbally interpreted as "Highly Manifested." The AWM rating is 3.01 which is verbally interpreted as "Highly Manifested." 
Table 12. Extent of Manifested Work Attitude along Incentives/Rewards

\begin{tabular}{|c|c|c|c|c|c|c|}
\hline $\begin{array}{l}\text { G. Incentives/ } \\
\text { Rewards. As teachers, we (are)... }\end{array}$ & $\mathbf{1}$ & 2 & 3 & 4 & Mean & DE \\
\hline $\begin{array}{l}\text { 1. Always receive my salary on time } \\
\text { with no delay. }\end{array}$ & 5 & 40 & 68 & 63 & 3.07 & $\mathrm{HM}$ \\
\hline $\begin{array}{l}\text { 2. Encouraged to work more because } \\
\text { the salary matches our efforts. }\end{array}$ & 1 & 47 & 67 & 61 & 3.07 & $\mathrm{HM}$ \\
\hline 3. Give importance to financial reward. & 5 & 31 & 89 & 51 & 3.06 & HM \\
\hline $\begin{array}{l}\text { 4. Satisfied with our teaching salary, } \\
\text { bonuses and other incentives we } \\
\text { received. }\end{array}$ & 3 & 49 & 81 & 43 & 2.93 & $\mathrm{HM}$ \\
\hline $\begin{array}{l}\text { 5. Feel ensured and stable in our } \\
\text { teaching salary. }\end{array}$ & 8 & 34 & 101 & 33 & 2.9 & $\mathrm{HM}$ \\
\hline Total & 22 & 201 & 406 & 251 & 3.01 & HM \\
\hline
\end{tabular}

The data imply that in any organization, money and financial benefits are important in intensifying organizational performance and maintained competitiveness. This is because compensation is the key element for employment. In addition to this, Dewhurst, et.al. [47] Discovered that reward is the most vital element in motivating employees for contributing their best efforts to get innovative ideas that cause better business functionality and further improvise company performance both financially and non-financially.

The powerful modes for encouraging employees for good performance is rewards. Armstrong [48] said that pay, recognition, promotion and quality of working life, and therefore the influence of the group with whom employees are being identified is said to be related to perception and attitude relevant to all the above-mentioned variables.

\section{Table 13. Summary Table on the Extent of Manifested Work Attitude}

\begin{tabular}{llcc}
\hline \multicolumn{1}{c}{ Variables } & Mean & DE \\
\hline a. Subjects taught & 3.50 & VHM \\
b. Superior/School Head & 3.34 & VHM \\
c. Co-workers & 3.32 & VHM \\
d. Learners & 3.48 & VHM \\
e. School environment & 3.33 & VHM \\
f. Parents & 3.45 & VHM \\
g. Recognition/award/promotion & 3.32 & VHM \\
h. Incentives/rewards & 3.01 & HM \\
\multicolumn{2}{c}{ Over-all Mean: } & $\mathbf{3 . 3 4}$ & VHM \\
\hline
\end{tabular}

Table 13 reveals that generally, the extent of manifested work attitude of the respondents is Very Highly Manifested. However, the extent of manifested work attitude along incentives/rewards obtained the lowest AWM of 3.01 which is verbally interpreted as Highly Manifested.

The result is in contrary to the study of Omolara and Adebukola [49] entitled Teachers' Attitudes: A Great Influence on Teaching and Learning of Social Studies which revealed that students' attitudes towards learning Social Studies were not encouraging. It is very obvious 
that only bad teachers will not help serious students who are able to learn. Nonchalant attitudes of the learners towards learning of Social Studies in secondary school could also result into poor teacher's attitudes towards teaching. When teachers are enthusiastic, students will tend to enjoy classes and feel excited about their subjects. Moreover, enthusiasm and excitement encourage students to possess a strong desire to learn a subject. (Alazzi [50])

The study also discovered that Social Studies teachers are not motivated by school heads and administrators as they do for others. Motivation is important in any worthy activities most especially in teaching. Motivations in form of praises, encouragement and compliment could enhance both teachers and students and can cause a change of attitude. On the opposite hand, if the teachers are left uncared for, their negative attitude could go from bad to worse and chaos may also result in a not conducive environment because they are the custodians of teaching civic rights.

Moreover, respondents also gave more manifestation on co-workers and school environment. The result agreed on the findings of Cajeta [51] on her study entitled Concretizing Values at Work: Exploring the Relation to Teaching Performance, where teachers have an interest interested to figure as a group in achieving his/her goal than doing it alone by himself/herself. They will become more productive when working as a team. They also want to be engaged in planning work, solving work problems, making decisions about work, and reviewing progress.

In addition, according to Bakotic and Babic [52] workers have a higher level of job satisfaction who work in normal working conditions than workers who work in difficult working conditions? The respondents are some of the most widely skilled people around to achieve success. A day in the life of a teacher can differ greatly depending on the subject and grade level in which they teach. From Kindergarten to high school and special education to statistics, one theme runs consistently in every great teacher's career.

Lastly, the result signifies that teacher compensation is still often believed as a policy strategy that could be used to develop student achievement, stimulate teachers' interests and make teaching very effective (Zebra, et al. [53]). In addition to this, according to Osunde and Izevbigie [54] teachers' salaries are very poor and therefore the little amount they receive is not even paid on time. They really suffer so much before being given their salaries. So, once they are not well fed and have enough money to provide for them and their immediate families, their inclination towards teaching will be negatively affected.

The relationship between the extent of manifested work attitude and teachers' performance was determined and illustrated in table 14. Pearson $r$ and Chi-Square Statistical Tests were used to test the significant relationship between the extent of manifested work attitude and teachers' performance.

As could be noted from the table, only two variables are significantly positively correlated to teachers' performance. The correlation of .197 between the extent of manifested work attitude along co-workers and the teachers' performance has a significance of .009 . This signifies that the extent of manifested work attitude along co-workers is significantly positively correlated to the teachers' performance at the .05 level of significance. It can be inferred from the findings that co-workers have an effect on the performance of the respondents. Thus, the null hypothesis which states that "There is no significant relationship between the extent of manifested work attitude and teachers' performance" was rejected. 
Table 14. Relationship between the Extent of Manifested Work Attitude and Teachers' Performance

\begin{tabular}{lcc}
\hline \multicolumn{1}{c}{ Extent of Manifested Work Attitude } & \multicolumn{2}{c}{ IPCRF } \\
\hline A. Subjects Taught & Correlation & Significance \\
B. Superior/School Head & .067 & .375 \\
C. Co-Workers & .025 & .739 \\
D. Learners & .197 & .009 \\
E. School Environment & .045 & .559 \\
F. Parents & .122 & .109 \\
G. Recognition/Award/Promotion & .090 & .234 \\
H. Incentives/Rewards $\quad .079$ & .299 \\
\multicolumn{1}{c}{ Over-All } & .168 & .025 \\
\hline
\end{tabular}

*Significance at .05 level

Relationship among co-workers are significant to individual employees. They promote better working relationships, which within the long run may develop the quality of work. Secondly, positive social interaction may enhance the emotional health of the staff community, thus reducing emotional stress and burnout. Moreover, interpretation of organizational policies is done more by colleagues than by supervisors. Thus, an employee's colleagues may influence significantly to his satisfaction, dissatisfaction and level of motivation while working in an organization. (Wainaina, J. [55])

The result also supports the study that employees have interactions with leaders and coworkers, and both types of relationships can be positive or negative. Theoretically, leaders can be supportive or antagonistic (Tierney \& Tepper [56]). Another survey administered amongst 1250 Food Brand employees discovered that positive relationships with co-workers can improve job satisfaction (Berta [57]). Co-worker support refers to employees' beliefs about the degree to which co-workers provide them with desirable resources within the form of emotional support and instrumental assistance (Chiaburu\& Harrison [58]).

It is likewise shown from the table that the correlation of the extent of manifested work attitude along incentives/rewards and the teachers' performance is .168 with a significance of .025. This indicates that the extent of manifested work attitude along incentives/rewards is significantly positively correlated to the teachers' performance at the .05 level of significance. It can be inferred from the findings that incentives are one of the most important elements in increasing the productivity of the teachers. These also help in encouraging the teachers to put forth their best and increase their enthusiasm at work. Thus, the null hypothesis which states that "There is no significant relationship between the extent of manifested work attitude and teachers' performance" was rejected.

As shown from the table, the correlation of the over-all extent of manifested work attitude along with the different variables and the teachers' performance is .120 with a significance of .116. This implies that there is no significant relationship between the over-all extent of manifested work attitude along with the different factors and the teachers' performance. The result signifies that this over-all extent of manifested work attitude along with the different factors has no effect on the teachers' performance. 
Furthermore, the null hypothesis which states that "There is no significant relationship between the extent of manifested work attitude and teachers' performance" was accepted.

Table 15. Correlation between Teachers' Performance across Teachers' Profile (Personal Attributes)

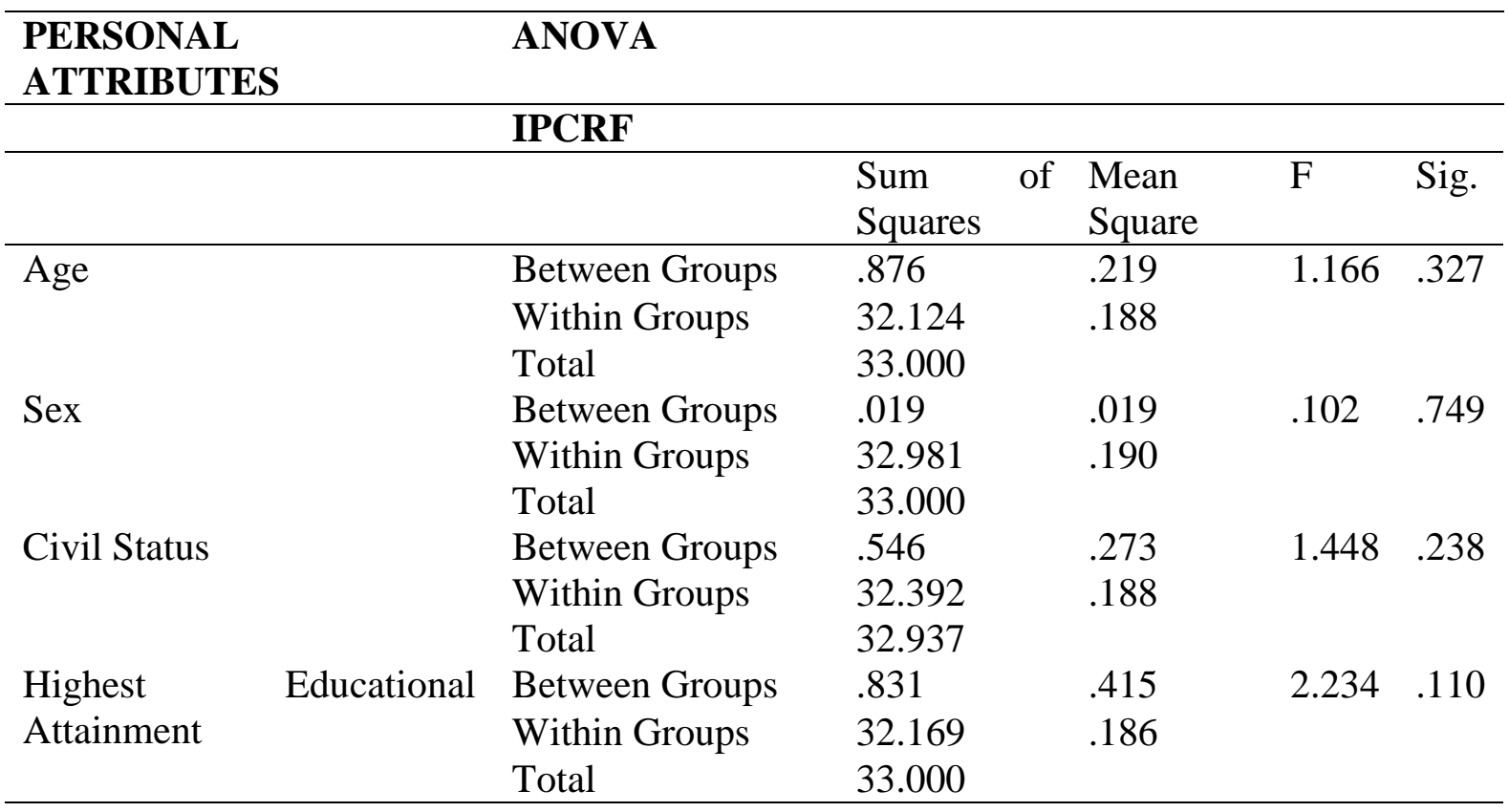

*Significance at .05 level

The correlation between the teachers' performance across teachers' profile in terms of personal attributes was determined and illustrated in table 15. T-test and Analysis of Variance were utilized to test the significant difference between the teachers' performance across teachers' profile.

As shown from the table as a result of t-test and analysis variance, the personal attributes of the elementary school teachers in terms of age, sex, civil status and highest educational attainment have computed p-value of $0.327,0.749,0.238$ and 0.110 respectively. Hence, it was concluded that there is no significant difference between the teachers' performance across teachers' profile in terms of personal attributes.

The result is in contrary to the report of Ahmed, Hussain, Ahmed, and Din [59] that the personal factors affect the performance of teachers. Similarly, this is also in contrary to the finding of Nadeem [60] that gender and age is a significant predictors of teachers' job performance. In addition to this, according to Onyekuro and Ibegbunam [61] that teacher qualification affects the effectiveness of the secondary school teachers. Another is the findings of De Ungria [62] that competencies of teachers differ significantly when they are group to age and length of service while educational attainment is not significant on their teaching competencies.

Table 16. Correlation between Teachers' Performance across Teachers' Profile (Professional Attributes)

*Significance at .05 level 


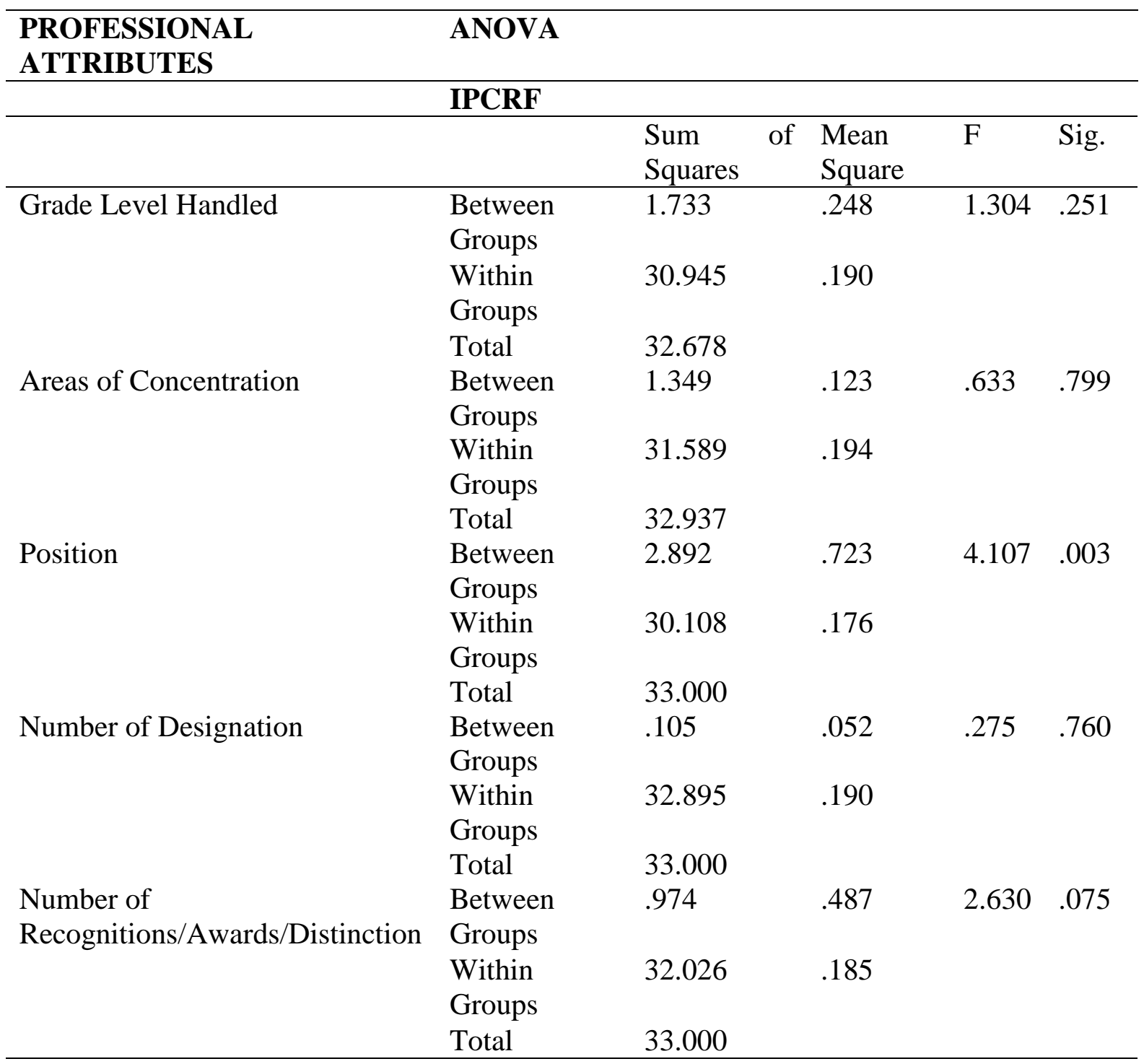

Table 16 illustrates the result of t-test and analysis variance which indicates that the professional attributes of the elementary school teachers have no significant difference except on position which has a computed p-value of 0.003 . This means that there is a significant difference between teachers' performance across position based on the significance value $(\mathrm{p}=0.003)$ lower than .05 level. It only proves that the higher the position the greater the teaching performance.

According to the RPMS manual, good teachers are important to raising student achievement. Thus, enhancing teacher quality ranks foremost in the many educational reform efforts toward quality education. The RPMS Tools have two different teacher performance assessment instruments: one for Teacher I-III (Proficient teachers) and another for Master teacher I-IV (Highly Proficient teachers). Teacher I-III are expected to be proficient in their practice and professionally independent in the application of skills vital to the teaching and learning process. While Master Teacher I-IV are expected to be at the highly proficient career stage. They should display a high level of performance consistently in their teaching practice. (Guidelines on the Establishment and Implementation of the Results-based Performance Management System (RPMS) [63]). 
The correlation between the teachers' performance across teachers' profile in terms of position under professional attributes was determined and illustrated in table 17.

It could be gleaned from the table, that there is a significant difference between Teacher I and Master Teachers I and II which have a mean difference of

-.50645 and -.40645 with a computed p-value of 0.001 and 0.046 respectively. This indicates that the teaching performance of Teacher I differs from Master Teachers I and II.

It is likewise shown from the table that there is a significant difference between Teacher II and Master Teacher I which has a mean difference of -.48261 with a computed p-value of 0.003 lower than the .05 level. This implies that the teaching performance of Teacher II differs from Master Teacher I.

It is further reflected from the table that there is a significant difference between Teacher III and Master Teachers I and II which have a mean difference of -.48505 and -.38505 with computed p-value of 0.001 and 0.046 lower than .05 level of significance. This signifies that the teaching performance of Teacher III differs from Master Teachers I and II.

The table also revealed that there is no significant difference between Master Teacher I and Master Teacher II which has a mean difference of 0.1 with a computed p-value of 0.664 . The finding implies that the teaching performance of Master Teacher I does not differ from Master Teacher II.

Table 17. Correlation of the Teachers' Position

\begin{tabular}{clcc}
\hline (I) Position & \multicolumn{1}{c}{$(\mathbf{J})$ Position } & Mean Difference (I-J) & Sig. \\
\hline Teacher I & Teacher II & -0.02384 & 0.837 \\
& Teacher III & -0.0214 & 0.803 \\
& Master Teacher I & $-.50645^{*}$ & 0.001 \\
& Master Teacher II & $-.40645^{*}$ & 0.046 \\
\multirow{2}{*}{ Teacher II } & Teacher III & 0.00244 & 0.98 \\
& Master Teacher I & $-.48261^{*}$ & 0.003 \\
\multirow{2}{*}{ Teacher III } & Master Teacher II & -0.38261 & 0.066 \\
& Master Teacher I & $-.48505^{*}$ & 0.001 \\
Master Teacher I & Master Teacher II & $-.38505^{*}$ & 0.046 \\
& Master Teacher II & 0.1 & 0.664 \\
\hline
\end{tabular}

*Significance at .05 level

The data support the Job Description released by the Department of Education (DepEd) [63] for Teacher I-III and Master Teacher I-IV. Teacher I-III duties and responsibilities include facilitating of learning, teaching using appropriate and innovative teaching strategies which are in accordance with the lesson plan, monitoring, updating, maintaining and evaluating learners' progress, counseling learners, supervising curricular and co-curricular activities/projects, maintaining harmonious relationship with fellow teachers, personnel, parents and stakeholders and does other related work. While the duties and responsibilities of Master Teacher I-IV comprise of the following: assumes leadership and prepares instructional materials in terms of instructional programs; conducts instructional training programs; provides professional assistance like coaching and mentoring teachers; develops and/or implements innovative functional teaching approaches and strategies; serves as demonstration teacher and/or consultant; conducts action research; leads analysis and utilization of test results and does other 
related work. Thus, Master Teacher I-IV does more supervisory tasks while instructional tasks are for Teacher I-III.

Furthermore, the null hypothesis which states that "There is no significant difference between the teachers' performance across teachers' profile" was rejected.

\section{Conclusion and Recommendation}

As an outcome of the findings presented in the previous discussions, the following conclusions are drawn: the respondents are female dominated, married, generally middle-aged with bachelors' degree. Most of them are generalist assigned in Grade 5 as Teacher III position with no designation and awards received. They demonstrated a Very Satisfactory teaching performance and manifested a very highly work attitude. The extent of manifested work attitude along with the different variables is generally Very Highly Manifested. The extent of manifested work attitude has nothing to do with teachers' performance. Teachers' performance differs across the position of the respondents.

Based on the foregoing findings and conclusions, the researcher recommends the following: (a) teachers shall persevere in pursuing advanced studies to equip themselves in their teaching career as part of their professional growth. (b) The conduct of team-building activities to foster camaraderie and social bonding among teachers and superiors or school heads will create an opportunity to have a positive interaction. (c) superiors/school heads shall provide support to build and sustain a high level of career aspirations of their teachers to promote positive attitude towards their work environment.

\section{References}

1) Meador, Derrick (2013). Problems for Teachers that Limit Effectiveness. Retrieved from www.about.com on December, 2019

2) Department of Education (2010). Discussion Paper on the enhanced K+12 Basic Education Program

3) Senemoglu, N. (2009). Development, Learning and Instruction: From Theory to Practice. Ankara:PagemA Publishing

4) Koksal, N. (2014). Competencies in Teacher Education: Preservice Teachers' Perceptions about Competencies and their Attitudes. African Journal of Philosophy 1910, 1-7

5) Abu Sharbain, I. and Tan, K. (2012). Pre-Service Teachers' Level of Competence and Their Attitudes Towards the Teaching Profession. Asian Journal of Social Sciences \& Humanities, Vol. 1, No. 3, August 2012

6) Guneyli, A. \& Aslan, C. (2009). Evaluation of Turkish Prospective Teacher's Attitudes Towards Teaching Profession. Procedia Social and Behavioral Sciences, 1, 313-319

7) Akkaya, F. (2009). Pre-Service Teachers`Attitude Towards Teaching Profession. Inonu University Journal of the Faculty of Education, 9(6), 27 - 42

8) Oguz, E. and Kalkan, M. (2011). Examining Teacher Candidates' Attitudes towards Teaching Profession and Pupil Control Ideology. International Online Journal of Educational Sciences, 2011, 3 (3), 903- 917 
9) Labadia, D. (2010). Organizational Commitment,Work Performance and Job Satisfaction Among the Faculty of the Religious of Virgin Mary (RVM) Schools in Southern Mindanao, Doctoral Dissertation, "Notre Dame University, Cotabato City"

10) Kesseler, S. (2007). The Effects of Organizational Structure on Faculty Job Performance, Job Satisfaction, and Counterproductive Work Behavior. Graduate Theses and Dissertations. https://scholarcommons.usf.edu/etd/2243

11) Fuming, X. \& Jiliang, S. (2007). Research on Job Satisfaction of Elementary and High School Teachers and Strategies to Increase Job Satisfaction. Chinese Education and Society, v40 n5 p86-96 Sep-Oct 2007

12) Okoye, A.U. (2011). Attitudes of Primary School Teachers Toward Introduction of Career Guidance in Primary Schools. A journal that cuts across all behavioral issues. Vol. 3. (No. 2)

13) Mccoy, M., Wilson-Jones, L., Jones, P. (2013). Selected North Carolina Beginning and Veteran Teachers' Perceptions of Factors Influencing retention and Attrition. Journal of Research Initiatives, 1(1)

14) Gagné, M., \& Deci, E. (2005). Self-Determination Theory and Work Motivation. Journal of Organizational Behavior. 26. 331-362

15) Okonkwo, M.C. \& Obineli S. A. (2011). The Roles of Counselling in Promoting Good Leadership: Anambra State on the Focus. A journal that cuts across all behavioral issues. Vol. 3 (No. 2)

16) Ewen, W. (2008). African Industrial- Organizational Psychology. Lagos, Nigeria: Pumark Publishers

17) Klecker, B., \& Loadman, W. (2011). Exploring the Relationship between Teacher Empowerment and Teacher Job Satisfaction. Midwestern Educational Research Association

18) Brown, J. S. \& Richard A. (2008) Minds on Fire: Open Education, the Long Tail, and Learning. Educational Review. Retrieved from http://net.educause.edu/ir/library/pdf/ERM0811.pdf on 05/10/2012

19) Galiza, J., Nicdao, R. \& Guidote Jr., A. (2018). Educational Attainment, Teaching Experience, Professional Development and Self-Efficacy as Predictors of Chemistry Content Knowledge: Implication for the Development of a National Promotion Examination. KIMIKA Volume 29, Number 2.

20) Hill, H. C. (2007). Learning in the Teaching Workforce. The future of children, 17(1), 111-127.

21) Miller, R., \& Roza, M. (2012). The Sheepskin Effect and Student Achievement: DeEmphasizing the Role of Master's Degrees in Teacher Compensation. Washington, DC: Center for American Progress

22) Collier, T. (2013). Teacher Qualifications and Student Achievement: A Panel Data of Analysis. Economics and Finance Faculty Publications, Paper 6. Retrieved from http://ecommons.udayton.edu/eco_fac_pub/6

23) Croninger, R. G., Rice, J. K., Rathbun, A., \& Nishio, M. (2007). Teacher Qualifications and

Early Learning: Effects of Certification, Degree, and Experience on First-Grade Student Achievement. Economics of Education Review,26(3), 312-324 
24) Harris, D. N., \& Sass, T. R. (2011). Teacher Training, Teacher Quality and Student Achievement. Journal of Public Economics, 95(7), 798-812

25) Henry, G.T., Bastian, K.C., Fortner, C.K., Kershaw, D.C., Purtell, K.M., Thompson, C.L., Zulli, R.A. (2014). Teacher Preparation Policies and their Effects on Student Achievement. Educ. Finance policy 9 (3),26-303

26) Jepsen, C. (2005). Teacher Characteristics and Student Achievement: Evidence from teacher surveys. Journal of Urban Economics, 57(2), 302-319

27) Rivkin, S. G., Hanushek, E. A., \& Kain, J. F. (2005). Teachers, Schools, And Academic Achievement. Econometrica, 73(2), 417-458

28) Hodges, T. (2017). Why Appreciating Teachers is More Important than You Think. Gallup Education Research, Gallup Inc.

29) Nemenzo, N. (2018). Problems Encountered by Teachers in the Teaching-Learning Process: A Basis of an Action https://www.researchgate.net/publication/324606765

30) Desimone, L. (2011). A Primer on Effective Professional Development. Sage Journals

31) Arnau, J. (2013). Reviving Catalan at School: Challenges and Instructional Approaches. ISBN 1783090278, 9781783090273

32) Hirsh, S.A. \& Hord, S.M. (2009). The Principal's Role in Supporting Learning Communities. Educational Leadership, 66(5), 22-23

33) Participant Media. (2010). Waiting For "Superman": How We Can Save America's Failing Public Schools. (K. Weber, Ed.) (1st ed). New York: Public Affairs

34) Hattie, J. (2015). The Applicability of Visible Learning to Higher Education. Scholarship of

Teaching and Learning in Psychology, 1(1),79-91

35) Piwowar, V., Thiel, F., \& Ophardt, D. (2013). Training Inservice Teachers' Competencies in

Classroom Management. A Quasi-Experimental Study with Teachers of Secondary Schools. Teaching and Teacher Education, 30, 1-12. doi:10.1016/j.tate.2012.09.007

36) Tauber, R.T. (2007). Classroom Management: Sound Theory and effective Practice. 4th ed. Westport, Conn.: Praeger Publishers

37) Kadtong, M.L., Unos,M., Amtok,T. \& Midzid, M. (2017). Teaching Performance and Job Satisfaction Among Teachers at Region XII. Proceedings Journal of Education, Psychology and Social Science Research, Vol.4, Issue 1, 2017

38) Aamodt, M.G. (2007). Industrial Organizational Psychology: An Applied Approach. Belmort: Thompson Higher Education

39) Lumley, M., Cohen, J. \& Keefe, F. (2011). Pain and Emotion: A Biopsychosocial Review of Recent Research. Journal of Clinical Psychology

40) Khan, P. \& Iqbal, M. (2012). Interdisciplinary Journal of Contemporary Research in Business. Vol. 4, No.3 P. 211

41) Jackson, C. (2014). Are Working Conditions Related to Teacher Effectiveness? 39th Annual Conference of the Association for Education Finance and Policy, San Antonio, Texas

42) Khong, L. (2016). Working with Parents to Support Students. SingTeach.nie.edu.sg 
43) Flynn, G. (2007). Increasing Parental Involvement in our Schools: The Need to Overcome Obstacles, Promote Critical Behaviors, and Provide Teacher Training. Journal of College Teaching \& Learning, 4(2), 23-30

44) Zeb, A., Rehman, S., Saeed, G., \& Ullah, H. A. (2014). Study of the Relationship Between Reward and Recognition and Employees Job Satisfaction: A Literature Review. Abasyn Journal of Social Sciences, 7(2), 278-291

45) Nyamubi, G. (2017). Determinants of Secondary School Teachers' Job Satisfaction in Tanzania.Hindawi Publishing Corporation Education Research International Volume 2017, Article ID 7282614

46) Sharma, J.P. \& Bajpai,N. (2011). Organizational Commitment and Its Impact on Job Satisfaction of Employees: A Comparative Study in Public and Private Sector in India. International Bulletin of Business Administration. Vol. 13, no. 2, pp. 97-118

47) Dewhurst, M., Guthridge, M. \& Mohr, E. (2010). Motivating People: Getting Beyond Money. McK-insey Quarterly, (1), 12-15

48) Armstrong, M. (2006). Employee Reward Management and Practice. London and Philadelphia: Kogan Page

49) Omolara, S. \& Adebukola, O. (2015). Teachers' Attitudes: A Great Influence on Teaching and Learning of Social Studies. Journal of Law, Policy and Globalization. Vol.42

50) Alazzi, F.K. (2013). Jordanian Students Attitudes towards Social Studies Education. The Journal of International Social Research. Volume 6:233

51) Cajeta, M. (2016). Concretizing Values at Work: Exploring the Relation to Teaching Performance. Journal of the Graduate School

52) Bakotic, D. \& Babic, T. (2013). Relationship Between Working Conditions and Job Satisfaction. The case of Croatian Shipbuilding Company. International Journal of Business and Social Science. Vol. 4. No.2

53) Zebra, et.al. (2006). Teachers Resources and Students' Achievements in High-Need Schools. Educational Development Laboratory. p4

54) Osunde, A.U. \& Izevbigie, T.I. (2006). An Assessment of Teachers' Attitude towards Teaching Profession in Midwestern Nigeria. Education

55) Wainaina, J.K., Kipchumba, S. \& Kombo, H. (2014). A Study on Effect of Co-Worker and Student- Teacher Relationship on Teachers' Organizational Commitment in Public Secondary Schools: A Case of Nakuru North District, Kenya. International Journal of Education and Research Vol. 2 No.2

56) Tierney, P. \& Tepper, B.J. (2007). Introduction to the Leadership Quarterly Special Issue:

Destructive Leadership. The Leadership Quarterly, 18 (3), 171-173

57) Berta, D. (2005). Put on A Happy Face: High Morale Can Lift Productivity. Nation's Restaurant News, 39(20), 8

58) Chiaburu, D.S. \& Harrison, D.A. (2008). Do Peers Make the Place? Conceptual Synthesis and Meta-Analysis of Co-Worker effects on Perceptions, Attitudes, OCBs, and Performance. Journal of Applied Psychology, 93 (5), 1082-1103

59) Ahmed, M., Hussain, I., Ahmed, S., and Din ud Qamar, M. (2012). The Factors Affecting the Professional Performance of Teachers at Higher Education Level in 
Khyber Pakhtunkhwa. Academic Research International, Volume 2, Issue, March 2012, 336- 341

60) Nadeem, M, Rana, M, Lone, A, Maqbool, S., Naz, K., \&Ali, A. (2011). Teachers Competencies and Factors Affecting the Performance of Female Teachers in Bahawalpur (Southern Punjab) Pakistan. International Journal of Business and Social Science

61) Onyekuro, B. U. and Ibegbuanan, J. O., (2013). Teaching Effectiveness of Secondary School Teachers in Emohua Local Government Area of Rivers State, Nigeria. European Scientific Journal, Volume 9, Issue 28, October 2013, 212-226

62) De Ungria, Julie M. (2013). Teaching Competencies and Pupils' Performance. Unpublished Thesis

63) Philippine National Research Center for Teacher Quality. Results-Based Performance Management System Manual for Teachers and School Heads. Department of Education - Bureau of Human Resource and Organizational Development 